\title{
INNOVATION CULTURE AND LEARNING: THE PROGRAM CLUBE DOS APAIXONADOS POR DESAFIOS (CHALLENGE LOVERS CLUB)
}

\author{
RICARDO PIMENTEL ${ }^{1}$ \\ (iD) https://orcid.org/0000-0003-1804-6691 \\ GUSTAVO F. LOIOLA ${ }^{1}$ \\ (iD) https://orcid.org/0000-0001-5017-7750 \\ THIAGO M. DIOGO \\ (iD) https://orcid.org/0000-0001-8482-2025
}

\begin{abstract}
To cite this paper: Pimentel, R., Loiola, G. F., \& Diogo, T. M. (2020). Innovation culture and learning: The program Clube dos Apaixonados por Desafios (Challenge Lovers Club). Revista de Administração Mackenzie, 21 (4), 1-25. doi:10.1590/1678-6971/eRAMG200129
\end{abstract}

Submission: June 21, 2019. Acceptance: Jan. 22, 2020.

1 Higher Institute of Administration and Economics (Instituto Superior de Administração e Economia Isae), Curitiba, PR, Brazil.

\section{(c) $\mathbf{B Y}$}

This paper may be copied, distributed, displayed, transmitted or adapted if provided, in a clear and explicit way, the name of the journal, the edition, the year and the pages on which the paper was originally published, but not suggesting that RAM endorses paper reuse. This licensing term should be made explicit in cases of reuse or distribution to third parties. It is not allowed the use for commercial purposes.

Este artigo pode ser copiado, distribuído, exibido, transmitido ou adaptado desde que citados, de forma clara e explícita, o nome da revista, a edição, o ano e as páginas nas quais o artigo foi publicado originalmente, mas sem sugerir que a RAM endosse a reutilização do artigo. Esse termo de licenciamento deve ser explicitado para os casos de reutilização ou distribuição para terceiros. Não é permitido o uso para fins comerciais. 


\section{ABSTRACT}

Purpose: The study analyzes the occurrence of learning through experience and the development of collective skills as a result of a program aimed to build a culture of innovation.

Originality/value: The study contributes to the theoretical discussion about innovation as a social process of experiential learning. From the practical point of view, it shows that the deliberate application of a method and a process in the construction of the innovation culture stimulates the learning of individual and collective abilities favorable to innovation, as well as behavioral and organizational changes.

Design/methodology/approach: Participant observation was used to compile the report, and an ex post facto survey based on in-depth interviews was used to evaluate the results. The analysis was based on the phenomenological semiotics with the support of Atlas.Ti® software in the process of description, reduction and interpretation, to apprehend the awareness of the subjects' experience.

Findings: The following results were obtained: 1. the occurrence of collective learning by the construction of solutions based on the combination of ideas of subjects with different perspectives and abilities, and by the deliberate application of a method and a process; 2 . building a new collective sense for innovation, as a constantly moving realization, requiring concrete behavioral changes, and a new look at reality. The study also pointed out that the theoretical approach that considers innovation as a social process of experiential learning contributes to the understanding of how the construction of the innovation culture takes place, and that this is part of the process of building innovation itself.

\section{KEYWORDS}

Innovation. Organizational innovation. Innovation culture. Innovation management. Organizational learning. 


\section{INTRODUCTION}

Since 1911, when Schumpeter (1982) first presented innovation as a creative force of capitalism, it has been approached from different perspectives. Over time, the concept has gone through views that prioritize the causal relationships between organizational characteristics and innovation, the role of internal and external resources, individual and organizational skills and competences, behavioral aspects, scales of measurement of innovation culture, among others, eventually reaching the perspectives that prioritize knowledge and entrepreneurial capacity as the origin of innovative transformations.

These different perspectives have raised some questions and some dichotomies that have emerged from theoretical studies and empirical evidence. One of these dichotomies was pointed out by Crossan and Apaydin (2010), who, after a systematic review of the literature, considered that the treatment given to the theme must comprise at least two dimensions: innovation as a process and innovation as a result.

In the first dimension, the authors highlight aspects such as the development and management of the mix of products and services, the decisionmaking process, as well as aspects related to the application of innovation, with a focus on the challenges involved in commercialization. In the latter dimension, the highlight is on the issues related to the target of innovation. Innovative products and services appear alongside changes in organizational and management models, expanding the scope of the concept beyond what is done by also considering how it is done. A bibliographic review pointed out some fundamental factors that must be present in any process that is intended to be innovative: the generation of ideas; selection and evaluation of techniques; and the implementation (Smith, Busi, Ball, \& Meer, 2008).

According to a literature review conducted by Bruno-Faria and Fonseca (2014a), in the studies on the relationship between culture and innovative processes, the quantitative approach predominates, and qualitative studies are necessary for a deeper understanding of the phenomenon. Faced with the practical challenge of implementing the innovation culture, the authors suggest the adoption of methods, such as an instrumental case study, and highlight the urgency of studies that use more complex research designs, including longitudinal cuts.

Despite this recommendation, Bruno-Faria and Fonseca (20014b, 2015) sought to build the basis for a measurement model for the innovation culture and then presented the results of building a scale for this measurement, 
even recognizing that the construct was still under development. In this sense, the present study follows the path initially proposed by the authors, in the sense of expanding knowledge about "how this relationship occurs [between culture and innovativeness], and how to contribute to the construction of the innovation culture in the organizational context" (BrunoFaria \& Fonseca, 2014a, p. 392).

Regarding the approaches with economic focus and of a quantitative disposition, others were added, emphasizing that the innovation is made by people and organizations, for people and organizations, being necessary a look at the social relations. Along these lines, the work of Uzzi $(1996,1997)$ contributed to the understanding of how the economic advantage that innovation provides for organizations and their networks is sustained by the interaction between social structure and economic performance, and in the relationships that result from them. For the author, this role of social relations is of fundamental importance, considering that economic relations are immersed and are shaped by the former.

Swedberg $(2006,2009)$ expands the relevant elements to the occurrence of innovation, such as values, behavior patterns, and cultural characteristics. For the author, any change in configuration that expresses itself in social change is innovation. This expansion of the concept of innovation brought into focus several aspects, among them, the innovation culture and learning with an emphasis on the production and sharing of knowledge, which also allowed an approach focused on social change, seen as the process of human development through of a set of capacities of social agents (Ziegler, 2010).

It is in this sense that the study makes a contribution, which is to expand the understanding of the construction of the innovation culture and its role in innovation itself. The article presents a research, whose objective was to analyze the occurrence of learning through experience, and the development of collective skills, as a result of a program aimed at building the innovation culture.

The Clube dos Apaixonados por Desafios (Challenge Lovers Club - CLC) program, which is the subject of this research, was based on four assumptions that guided its preparation by the Innovation Committee of the studied organization: 1. innovation depends on learning, and both are social phenomena; 2. learning depends on enriching the experience and takes place in a transaction (Dewey, 1987); 3. an environment favorable to innovation is one that allows the enrichment of experience and the learning of individual and collective skills, such as associating, observing, questioning, creating networking and experimenting (Dyer, Christensen, \& Gregersen, 2011); 
4. the use of collective knowledge production techniques such as Design Thinking, Business Model Canvas (BMC) (Osterwalder \& Pigneur, 2011), and Lean Canvas can be used deliberately by organizations that seek to be more permeable to innovative processes.

The methodological procedures adopted were defined given the research objective and the CLC assumptions. For the elaboration of the program report, participant observation was used; and for the evaluation of the results, an ex post facto research based on in-depth interviews with some of its participants. Data analysis used phenomenological semiotics (Lanigan, 1997, 2013).

\section{THEORETICAL FRAMEWORK}

The assumptions that inspired the present study were built from the perspective of some authors who supported the main concepts used: innovation culture, learning, and experience.

\subsection{Innovation culture}

The relationships between organizational culture and innovation have been the subject of several studies and with different approaches (Ahmed, 1998; Bretell \& Cleven, 2011; Bruno-Faria \& Fonseca, 2014a, 2014b, 2015; Gomes, Machado, \& Alegre, 2015; Harbi, Anderson, \& Amamou, 2014; Kaasa \& Vadi, 2010; Martins \& Martins, 2002; O’Reilly \& Tushman, 2007; Uzkurt, Kumar, \& Ensari, 2013). In all of them, it is possible to verify the increasing importance of intangible aspects and the perspective that takes innovation as a social construction (Dobni, 2008).

The concern with evaluating how, and in what intensity innovation happens or can happen in an organization also occurs by different criteria that go beyond the economic aspects. The innovative capacity comes to be seen from the conditions it has in providing the production, recognition, and sharing of new knowledge, as well as its application in the multiple organizational processes and the development and commercialization of new products and services. It is no longer enough to talk about innovation and organizational culture in a watertight way but to focus on the innovation culture.

Ahmed (1998) already pointed out that the organizational climate, interpersonal relationships, and working conditions are important factors for an organization to be innovative, all of them visible and measurable. The 
biggest challenge is in building values and beliefs that support the innovation culture, as they operate at a deeper level, but that can be created from the influence exerted on the interpretations and cognitive schemes of individuals. This perspective brings up some contradictory aspects as it values the role of the individual and of the organization at the same time, putting in question the dilemma between intervening in a collective and organizational level, or at an individual level.

In more recent proposals, there is an approach that understands that the innovation culture is complex and multifaceted and cannot be approached as a mere unfolding of organizational culture, nor in a one-dimensional way. Thus, Davies and Buisine (2018), based on a bibliographic review, propose a model with five non-hierarchical dimensions. The acronym ETOILe, in French, includes the aspects of environment, team, organization, individuals, and leaders, and demonstrates an effort to develop a vision that is both diverse and unified in the phenomenon of the innovation culture.

One of the merits of the model is that it indicates that technical and objective dimensions are necessary, but not sufficient for the organization's capacity to innovate and that the innovation culture is a historical social construction, and its relationship with innovation has more to do with it becoming organizational than with the here-now.

The program which is the object of this study was inspired by the challenge of promoting the construction of the innovation culture, based on the construction of skills necessary for individuals to become agents of innovation (Dyer et al., 2011) in such a way that knowledge can be produced, shared and incorporated at the organizational level. To this end, it adopted an approach based on learning from transformative experiences, an approach discussed in the following section.

\subsection{Experience and learning}

Dewey's contribution $(1981,1987)$ was fundamental for the evaluation of CLC and its results, especially because his learning theory is an effort to integrate the individual cognitive aspect with the dimension of social interaction (Elkjær, 2004). For him, the individual works with the reflections made in past situations to build knowledge in the current situation, and learning is the process of building experiences and becoming aware of them, focusing on the transaction between the individual and his environment. This transaction is, in itself, an experience constructed in a way situated in time and space and enriched in the process of awareness by the individual, 
who, in doing so, acquires the capacity to transform oneself and to transform the physical and social environment. The experience in this perspective is not the static result of something that happened in the past, but a movement that links the past to the present through reflection.

To better understand the concept of learning according to Dewey (1981), it is necessary to comprehend the importance that is attached to experience. Experience is both an object and a method, as reflection is itself an experience that produces objects of reflection and makes primary objects explicit, enabling them to be grasped by understanding. The empirical is not the manifestation of the separation between subject and object; on the contrary, they are both content and a result of reflection.

Dewey (1998) developed the notion of continued experience, which is nothing more than the idea that an experience remains present in subsequent experiences, considering that an experience modifies and influences the way experiences occur later. All learning takes place in an experience, whether or not it favors learning. This difference is clearly linked to the quality of these experiences and, in particular, to the ability to keep the individual moving in search of something he/she does not have.

For Elkjær (2004), Dewey's contribution to studies on learning in the organizational environment is in the fact that the unit of analysis is a problem configured in a given situation and, therefore, is located neither in the individual nor the in organization, but in the transaction and its temporal and contextual developments. Inquiry, a fundamental concept in the Deweyan thinking, is the method for gaining experience and building knowledge. Being used in daily life, research is born out of a problem or a situation to be modified. It uses past experiences and builds a new experience. Dewey (1998) argues that this method should be used in intentional learning processes (Buch \& Elkjær, 2015; Elkjær, 2000).

These are some aspects that guided the present research, and in the following sections the methodological procedures adopted are presented, further details on the CLC program, followed by the analysis and the main results.

\section{METHOD}

The research was based on data collection, carried out in two distinct, but complementary moments. The first moment, which took place between April and November 2017, refers to the period of elaboration, planning and execution of the CLC program by the institution's Innovation Committee. 
In this phase, participant observation was carried out with the elaboration of a diary, composed of field notes; also, a collection was made through informal conversations, capture of images, and compilation of documents produced by the Innovation Committee, as well as by the groups participating in the program, such as meeting minutes and action plans. Such data was used to support the analysis of the information collected in the second moment of the research, besides being used to compose the report of the process.

The second moment was an ex-post facto research. The data collection was based on in-depth interviews with ten participants and occurred after the end of the program. The goal was to evaluate the results concerning the construction of the innovation culture. The interviews, which focused on their lived experiences, were recorded and transcribed.

Data analysis used Lanigan's phenomenological semiotics $(1997,2013)$, in which special attention is given to language as a way to access the meaning given by the subject to his/her lived experience. For the author, experience is the flow between perception (what is experienced -capta), and expression (what is the result of the thought process - data). The apprehension of this flow allows the refinement and increasing clarity of perception and expression as a process to access the subject's consciousness.

The analysis used the Atlas.Ti 8.2.33® software and followed three procedures: 1. phenomenological description, which focuses on discourse as a system of signs and seeks to raise relevant themes and expressions related to the research objectives; 2. phenomenological reduction, in which the expression of meaning is sought through revealing phrases, also called units of meaning, and in which the focus is on the signifiers in the sign system; and 3. the phenomenological interpretation, in which the perception of the senses with a focus on meaning is sought, here called categories.

The first phase identified 21 relevant expressions related to the research objectives. Through phenomenological reduction, six units of meaning were reached. From these, the researchers returned to the data for a new reduction effort, which reached three emerging categories and guided the presentation of the analysis and results. Based on them, the next section was built, in which the results obtained and the analysis are hereby presented.

\section{RESULTS PRESENTATION AND ANALYSIS}

In this section, we present the context, with a report on the process of creating and implementing the program that is the object of study. Subse- 
quentially, the phenomenological analysis of the data and the results of the program identified in the ex post facto research are presented.

\subsection{Investigated context and reality}

The Instituto Superior de Administração e Economia (Higher Institute of Administration and Economics - Isae) is a business school located in the city of Curitiba, in Paraná, it was created in 1996, derived from the strategy of an existing renowned higher education institution, which sought to expand its activities. Isae has always been guided by the policies of the original institution, but also sought to adopt an innovative and transversal stance, investing in the construction of its own strategic values, such as governance, innovation, sustainability, entrepreneurship, leadership and ethics. In the beginning, it offered lato sensu postgraduate courses from the original institution, yet over time, it also started to offer its own services, such as undergraduate courses, lato and stricto sensu postgraduate courses (master's degrees). At the time the program and the research reported here were being carried out, the organization had around 130 employees.

The end of 2016 at Isae was marked by discussions about the strategic importance of innovation. As one of the institution's strategic guiding concepts, the theme was not new, but it was in evidence, especially in the discussions of the strategic planning of the following year.

This highlight was due to the fact that the leaders consider the need to create an environment favorable to innovation, so that it ceases to be just a principle and becomes a concrete element. This direction was based on a previous empirical research that pointed out that: 1 . innovation was present in organizational values, but it was not incorporated in concrete individual and collective activities; 2 . innovation was seen as an individual and behavioral activity, parallel to everyday activities (Pimentel, 2019).

For Isae's board, despite the concrete results obtained in the activities of the organization as a whole, there were some limitations to be overcome. The situation was close to that described by Ahmed (1998), in which organizations are often taken to a contradictory position to value and defend innovation as a discourse, without effectively incorporating it in their activities and decisions, due to the risk that is inherent in it.

Thereafter, the Innovation Committee was reoriented and began to focus its strategies and actions on the creation of a cultural environment favorable to innovation, considering that it involves the incorporation of explicit or not explicit routines and standards over time, ways of doing them and principles (O’Reilly \& Tushman, 2007). 
The Committee chose to start the work by deepening the discussion on innovation. The weekly meetings, lasting one hour, were divided into two parts of half an hour each. In the first part, the group reflected and discussed innovation, based on materials selected by both the coordinator and the other members. In the second part, the group focused on the elaboration of possible practical paths, which was initially accomplished by building a bank of ideas, according to the minutes of the Innovation Committee meeting (Isae, 2017), which culminated in the elaboration of an action plan.

From this process came the CLC, which is presented in detail in the next section.

\subsection{The Challenge Lovers Club Program}

The main objective of CLC was to develop a favorable environment for innovation and its incorporation into the concrete activities of the organization, thus impacting its innovation culture. Based on the assumptions and objectives previously discussed, the Innovation Committee designed the process that led the CLC with six steps focused on collective production, as shown in Figure 4.2.1. In the first one, employees were invited to propose challenges that they considered relevant to the organization, by filling in a form with questions, which were available on the organization's intranet that led to reflection. This phase was accompanied by a "hand-to-hand" work carried out by the members of the Innovation Committee with the members of the organization, emphasizing that more than suggesting solutions to problems, what was sought was a reflection on these problems, aiming to go beyond what had already been given.

\section{(Figure 4.2.1)}

PROCESS: THE STAGES OF THE CHALLENGE LOVERS CLUB

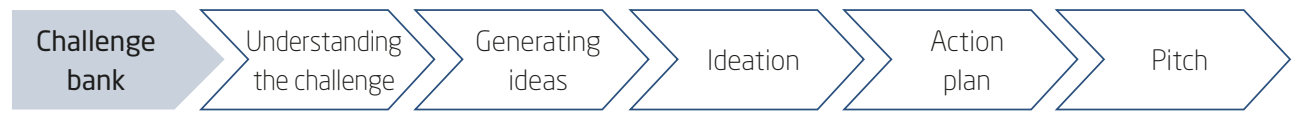

Source: Elaborated by the authors.

For the Innovation Committee, the main objective was to develop the ability to observe reality and to inquire. After being curated by the Innovation Committee, of a total of 23 challenges, four were selected for the execution of the program. These four challenges were presented and 27 employees, then, applied to participate in the groups that would work on each challenge. 
From then on, the process followed an evolutionary flow in the following five stages: understanding the challenge, generating ideas, ideation, action plan and pitch. Figure 4.2.2 presents a summary of each stage, the activities developed, and the techniques used.

(Figure 4.2.2)

STAGES OF THE CHALLENGE LOVERS CLUB PROGRAM

\begin{tabular}{|c|c|c|}
\hline Stage & Activities & Technique \\
\hline $\begin{array}{l}\text { Understanding } \\
\text { the challenge }\end{array}$ & $\begin{array}{l}\text { Participants interviewed each challenger about the context } \\
\text { and the reasons that guided the challenge proposal while } \\
\text { taking notes relevant to the following phases. }\end{array}$ & Deep diving \\
\hline Generating ideas & $\begin{array}{l}\text { Generation of ideas followed by the discussion and } \\
\text { prioritization process, from which the participants came } \\
\text { out with some ideas chosen to be developed, emphasizing } \\
\text { that they were the first collective production of each group. }\end{array}$ & $\begin{array}{l}\text { Brainstorming and } \\
\text { brainwriting }\end{array}$ \\
\hline Ideation & $\begin{array}{l}\text { Unlike the classic notion of target audience, the creation } \\
\text { of the persona invests in the creation of personal } \\
\text { characteristics, such as physical aspects, life history, and } \\
\text { motivations. This is important to generate empathy and to } \\
\text { humanize the relationship, enriching the process of } \\
\text { creating the empathy map. This, in turn, is a tool that helps } \\
\text { the group to role-play and empathize, through imagination. }\end{array}$ & $\begin{array}{l}\text { Creating personas } \\
\text { and empathy } \\
\text { mapping }\end{array}$ \\
\hline Action plan & $\begin{array}{l}\text { Implementation and operationalization of the proposed } \\
\text { ideas, by identifying the elements necessary to meet the } \\
\text { needs of the persona created, and by creating projects } \\
\text { capable of meeting these needs, taking into account the } \\
\text { challenge proposed for each group. }\end{array}$ & $\begin{array}{l}\text { Value proposition } \\
\text { mapping, Business } \\
\text { Model Canvas, and } \\
\text { Lean Canvas }\end{array}$ \\
\hline Pitch & $\begin{array}{l}\text { Creation of a pitch to present the proposal to Isae's board, } \\
\text { with two objectives: } 1 \text {. to develop the participants' capacity } \\
\text { for synthesis; } 2 \text {. to arouse the interest of the institution's } \\
\text { governing body in carrying out its implementation. }\end{array}$ & $\begin{array}{l}\text { Orientation of } \\
\text { each group by the } \\
\text { tutors. }\end{array}$ \\
\hline
\end{tabular}

Source: Elaborated by the authors.

\subsection{Phenomenological data analysis: CLC results}

As described above, Figure 4.3.1 presents the synthesis of the phenomenological analysis of the data, with the emerging categories and the units of meaning that guided the presentation of the results. 


\section{(Figure 4.3.1)}

SYNTHESIS OF PHENOMENOLOGICAL ANALYSIS

\begin{tabular}{|c|c|}
\hline Emerging categories & Meaning units \\
\hline \multirow{3}{*}{$\begin{array}{l}\text { Learning through awareness of } \\
\text { collective production }\end{array}$} & Individual and collective action. \\
\hline & $\begin{array}{l}\text { Frustration with the group and with the process as } \\
\text { generators of reflection and action (inquiry). }\end{array}$ \\
\hline & Conflict between individual and collective creation. \\
\hline \multirow[t]{2}{*}{ Learning through process and method } & $\begin{array}{l}\text { Frustration with the group and with the process as } \\
\text { generators of reflection and action (inquiry). }\end{array}$ \\
\hline & Overcoming limiting beliefs through experience. \\
\hline \multirow[t]{2}{*}{ Meaning of post-experience innovation } & Innovation as a change of perspective. \\
\hline & Innovation as a continuous process of (re)construction. \\
\hline
\end{tabular}

Source: Elaborated by the authors

\subsubsection{Learning through awareness of collective production}

Throughout the elaboration of the program, the Innovation Committee was concerned with reinforcing the idea that one of the fundamental objectives was collective production. This was due to a belief shared by the group that there was a "father-of-the-child syndrome" that was manifested in the resistance that employees had when giving suggestions, because they understood that whoever did it ended up being responsible for its operation and implementation. In an organization of the size of Isae, this led to an accumulation of activities and responsibilities. This concern was reflected in the definition of two criteria for the formation of working groups: 1. the groups should be formed with employees from different areas; and 2. the employee who proposed the challenge could not join the group that would face its own challenge.

In the beginning, it was possible to perceive the occurrence of situations that provided the conditions for enriching the experience and the occurrence of learning. After the formation of the groups, a meeting was held with all participants, in order to present the program and its various stages, as well as what was expected as a result. At that meeting, one of the participants, who had also registered a challenge that was chosen among the four, strongly expressed her dissatisfaction at not being able to solve her own challenge, arguing that she had many ideas, and considered the fact that those directives were unfair and unproductive. Thanks to this intervention, it was possible 
to clarify that the proposition of a challenge already contained the ideas for solving it, reducing the possibility of reaching something new and that the main objective of the program was to develop the collective skills necessary for innovation, to contribute to the construction of the innovation culture.

In the final phase of the process, this same participant declared, in an informal conversation, the importance of the rule established at the beginning, and how enriching it was to address a challenge that she did not have in perspective, and especially when sharing this process with other members from different areas and with whom she had never interacted. This fact points to the importance of creating intentional situations as a part of the learning process (Buch \& Elkjær, 2015; Dewey, 1998; Elkjær, 2000).

Some interviewees stated that they experienced a feeling of frustration with the group, which can be summarized in two aspects: 1. the imposition of ideas and 2. awareness of the non-originality of the proposed solutions.

Regarding the first aspect, an interviewee's statement is presented:

I want something to happen [...] I'm going to do this here, and now, I'm going to force this idea along this path [...]. And I saw not even one person trying to do that. Several people. As if they always wanted to hammer the same idea anywhere in order to make it happen. Hence, this ends up halting the generation of new ideas and de facto innovation. Because you are actually using a means of innovation to impose things you want. It is not how it works. I felt that a little bit (E3).

The reported difficulty points out that, in collective construction, the process itself led to an individual-collective conflict. As the conduct was guided by the use of collective techniques, this difficulty was configured as a motivating element in the awareness of the participants concerning this dimension. The creation of the persona, the empathy map, the mapping of the value proposition, and the BMC triggered a result in which the individual contributions were surpassed by the collective construction. In concrete terms, the discomfort of a moment reinforced and valued that result, as highlighted by an interviewee:

I think that the methodology favored thinking together. I didn't just have my own idea, we had to think together. So, it enabled us, because everyone contributed [...] there was a real exchange and a discussion, "this will work, this will not, let's go this way, let's go the other way". I think those moments were rich because they really favored this teamwork. And I think that it was really important (E7). 
Regarding the second aspect, the analysis of the collected data allowed the team to identify the importance of its occurrence when it comes to the construction of the innovation culture. At a certain point in the program's execution, participants from more than one group believed that some of the paths outlined were similar to what was already being thought and executed at the institution. Regardless of the veracity of this perception, the fact caused demotivation in some of them, according to the words of one interviewee:

It was when I understood that, within the project that we were participating in, there were already several options we were putting in place and they were already being developed by the company. I think this should have been presented to us a little earlier, because when we had already had some ideas, then someone said "so-and-so is already doing it, another area is already doing it, thingy is already doing it". It was frustrating, not because ours was the best, but knowing that we were working on a project that was already underway (E2).

An occurrence that was apparently limiting ended up reinforcing the process and its objectives. When dealing with "that was already being developed by the company" the group had to face the limitation of its own ideas. What appeared to be an idea of a participant or even of the group was actually an idea shared more widely and, therefore, apparently less innovative. This experience also provoked reflection and a broader understanding about the role of collective work in the creation of the innovation culture, as it influenced the interpretations and cognitive schemes of individuals (Ahmed, 1998), besides contributing to the constitution of a group capable of developing collective genius (Hill, Brandeau, Truelove, Lineback, \& Johnsonl, 2014), as exemplified by the following excerpts from two interviews:

When we started to suggest some solutions, there was that conflict with what was already happening here at Isae. [...] Everyone saw this as an impediment [...], but then it was rescued, "no, we have to consider the scenario as it is today". What will happen will still happen. So, this is (sic) still project ideas of ours anyway. Ok, let's deal with what we know may happen (E4).

Regarding the result, I thought it was cool because I realized that people ended up coming across things that the whole company is thinking about. That was... it seemed like synergy (E3). 
In the two aspects presented in which the feeling of frustration was manifested, the increase in the group's awareness of the collective character of the production generated learning by expanding the capacity to use the experience in an enriching way.

\subsubsection{Learning by process and method}

As the objective of CLC was to foment an environment favorable to innovation through the development of individual and collective skills (Dyer et al., 2011), the method and process previously described were established. The analysis of the data revealed that both caused the occurrence of learning and that it may be called collective learning, considering that it happened through transactions (Dewey, 1987, 1998) and resulted in solutions built by the combination and crossing of ideas from people with different skills and perspectives, that is, there was the so-called collective genius (Hill et al., 2014). The following is some evidence that demonstrates the findings of this research.

Participants were required to apply the techniques of the method, which depended on diving into a particular activity that was seemingly disconnected from the final objective of each group. One of those moments was the creation of the persona and the elaboration of the empathy map, which purposely took place in a coworking space outside Isae facilities. The objective was precisely to create an environment freer from symbolic and material references of the participants' daily life, causing a distance and a deepening in this stage. Although several interviewees reported the importance of this moment, there were also reports that showed frustration with the process, claiming it seemed confusing and meaningless:

So, I thought that some parties didn't connect, I think that, when we went to the coworking space, I had a little difficulty. I did not see the questions in the project like that. That was the most difficult part. Because they were very technical questions for something that cannot be so technical (E1).

Despite this relative limitation, a triangulation of data from the participant observation with the interviews detected that the distance and the desired deepening in fact occurred. Not understanding the meaning momentarily contributed to the learning, as it provokes a reflection on what is generated by the participants and the members of the Innovation Committee who conducted the activities, some of the adjustments that 
needed to be made in the questions used in making the map of empathy. Despite the departure of an individual situation, it generated an inquiry (Dewey, 1998) that impacted the group, and since then it has rebuilt a tool, in order to become more to achieve the group's objectives, as well as the others, contributing to improving the method.

In addition to this adaptation, there was also the inclusion of a new tool at the initiative of one of the groups, whose challenge was to focus on quality issues in customer service. When faced with the limitation in knowing all the relationships between the institution and its students, and with significant diversity in the view that the participants had of these relationships, the group opted to adopt the construction of the client's journey (Meroni \& Sangiorgi, 2011; Stickdorn \& Schneider, 2010). This made it possible to build collective knowledge on the topic, which allowed diversity to be used to enrich the experience.

This adoption had two consequences: 1. it made the group resort to the "already known" and 2. the inclusion of the tool required more time to conduct the process. This proposition took the group to a different path from the others and, because of the previously established schedule, the result fell short of an innovative proposal and was limited to a diagnosis of the situation. It is not that it prevented the generation of innovative ideas, but it rebuilt the path, which would require more time, still, that resulted in continued learning (Dewey, 1998) generated by the application of the method and the process. Even so, the final proposal of the group included the creation of a new position at the institution, called the customer relationship manager (GRC), which was put into practice the following year under the name of student relationship manager (GRA), and the hiring of a professional whose role was specific for this function.

The second evidence of the occurrence of learning by the method and the process occurred in relation to overcoming limiting beliefs, such as: 1 . it is only possible to apply a method and carry out a process with prior training, and 2. organizational culture tends to prevail.

The belief that people need to be trained to do something can be overcome when this action is collective and built based on a method and a process that privileges collective construction. Some pieces of evidence that this happened in CLC are the facts reported above, as well as the interview excerpt below:

I think we should have undergone training before [...] Then, when the methodology was presented, we managed, or at least I managed, 
to see that I was wrong, I was mistaken that the innovation process is not always assertive and it is not always the best. This, too, I found positive, and the best part for me was the integration. And I realized that my pain was the same as the others'. My pain was affecting the other's challenge, and so on (E8).

The second limiting belief, that the CLC contributed to call into question, concerns the notion that organizational culture makes change difficult. The conduction of a program based on activities of collective production allows the living experience of the (re)construction of our own culture. Below is another excerpt of an interview that exemplifies the findings of this research.

I found it more because of the company's culture. In this sense, we have several projects, we run several projects at the same time and we are unable to finish a project, to have a beginning, a middle and an end. So, it demotivated me at first. After talking to other people, which I think is the part that was most valuable, I realized that I left this issue aside, that it is a company's culture, little by little it can be changed $[. .$.$] talking to others I realized that, in addition to the pro-$ ject itself, I could learn more and have better integration with the other areas (E9).

The elements presented in the discussions carried out above are directly related to the last emerging category identified in the data analysis that will be discussed below.

\subsubsection{Meaning of post-experience innovation}

Before starting the discussion of this section, it should be noted that more than just a concept of innovation, what was identified in the data analysis was a change in the perception of the participants regarding the sense of innovation as a product of the lived experience. In this premise, one of the most striking aspects was the experience of creating a new look at reality from small, but important details. This led the participants to realize that it is precisely by sharing perspectives that these details gain visibility and importance. In addition, this change in perspective was accompanied by the deconstruction and reconstruction of the understanding of reality, in the strict sense of what Dewey $(1987,1998)$ calls transaction. A testimonial is especially revealing: 
What we have experienced in this is that it is not making a gigantic transformation, it is perhaps from one point of view, to look with a different perspective. A look that is not of what you have built with your base, what you have always been used to. You look at it without any kind of judgment [...] and see that you can create, from a small idea, without wanting to make big changes with big things [...]. Deconstruct a little of everything that was built [...] And everything at the end was a junction: I said this, another person said that, and a plan was built (E5).

Likewise, the participants identified innovation as an achievement in constant construction and that this relates to the use of a method and process that were previously defined, but at the same time were (re)constructed throughout the experience:

So, I started to understand that it is not like that, you arrive totally excited and you think that the project has to have a beginning, a middle and an end, everything is cute, everything is round and there can be no deviations. And it's not. The innovation process is long and does not resolve overnight (E6).

It is very difficult to collaborate and innovate. You need to have "soooo much" patience. [...] And incredible as it may seem, you talk about innovation, you think of something fast, something like that for yesterday. I do not think that, in practice, it is so. [...] I think that innovation requires "sooo much" patience and collaboration. And at the same time that you are not [...]. You have to know how to balance, impose yourself and have a little patience. It's almost like Buddhism, you know [laughs] (E3).

This experience allowed participants to associate the program with the development of something innovative and was associated with an awareness of the need for behavioral changes, and their concrete occurrence.

\section{CONCLUSIONS AND RECOMMENDATIONS}

In view of the research objective, and the theoretical perspective adopted, it can be concluded that the CLC contributed to the construction of the innovation culture at Isae, as it allowed the occurrence of learning in a sense given by Dewey $(1987,1998)$ and the development of collective skills. 
With regards to the collective character of innovation, there was a substantial increase in the awareness of the participants, both due to the emergence of conflicts between the individual and collective dimensions of this production, as well as to the situations in which the feeling of frustration with the group served to show the participants the importance of the group itself. In both cases, participation in the CLC led to the expansion of the participants' ability to use the experience in an enriching way.

The CLC method and process also promoted collective learning when they made the individual and group limitations explicit, generating inquiry (Dewey, 1987, 1998), deepening reflections and the (re)construction of the method and the process, also contributing to increasing awareness of the collective production of innovation.

Another aspect identified by the research was the occurrence of overcoming limiting beliefs, which contributed to the change towards the creation of the innovation culture. The participants realized that it is possible to carry out a project together without being subject to previous training, as collective production allows learning by doing and doing by learning, and that this ability can be used in the (re)construction of the innovation culture.

The participants were able to give a renewed sense to innovation by understanding that, in collective production, different perspectives compete, allowing a new look at reality and at what innovation is. The use of a method previously defined, and (re)built throughout the experience, was the basis for this new sense, in which innovation came to be understood as a realization in constant movement, which requires concrete behavioral changes.

The study also pointed out that the theoretical approach that considers innovation as a social learning process contributes to the understanding of how innovation culture is built, and that it is part of the innovation construction process itself.

The research results also point out that the main objective of the program implemented by Isae has been achieved, which is to foster a favorable environment for innovation through the development of individual and collective skills (Dyer et al., 2011). The program also developed the innovation culture by valuing intangible aspects and social change, investing in improving the capacities of social agents (Dobni, 2008; Ziegler, 2010).

This was fundamental, because the CLC created, deliberately, a set of situations that provided the conditions for enriching the experience of the participants, and the occurrence of learning, which can be called collective learning because of what happened through transactions, and the construction of solutions was the result of crossing and combining the ideas of 
subjects with different perspectives and skills (Dewey, 1987, 1998; Hill et al., 2014).

From a practical point of view, the study showed that one of the assumptions that supported the CLC, namely, the deliberate application of method and process in the construction of an organization's innovation culture, provokes the learning of individual and collective skills favorable to innovation, in addition to significant behavioral changes.

Nevertheless, we recognize some limitations of this study. Due to the nature of the program, it was not possible to make an assessment of the participants prior to the beginning of the program, making it difficult to understand the scope of the changes caused and captured in the research. Similarly, the time frame of data collection did not allow a longitudinal follow-up to assess the program's reflexes over a certain period.

Due to the practical implications of the study, as well as the need to overcome the limitations mentioned, it is recommended: 1 . the planning of new researches simultaneously with the application of the program, in such a way that it is possible a prior evaluation of the conditions in relation to the innovation culture; 2 . the application in organizations of diverse nature, such as industries, public sector and third sector organizations, in addition to the application in large organizations; and, finally, 3. the realization of a study of greater time span, in order to expand the longitudinal analysis of the results. The application of the program in these new conditions also opens up the possibility for new research, which seeks to identify particularities due to this diversity, as well as to monitor the results. To conclude, it is worth mentioning that CLC has become part of the IES service portfolio, making up the practical part of a training program for innovation agents. At the time of writing this article, the program was being applied to more than six hundred professional cooperatives in the states of Paraná, Goiás and Mato Grosso do Sul.

\section{CULTURA DE INOVAÇÃO E APRENDIZAGEM: O PROGRAMA CLUBE DOS APAIXONADOS POR DESAFIOS}

RESUMO

Objetivo: O estudo analisa a ocorrência de aprendizagem pela experiência e o desenvolvimento de habilidades coletivas como resultado de um programa voltado à construção de cultura de inovação. 
Originalidade/valor: O estudo contribui para a discussão teórica acerca da inovação como um processo social de aprendizagem experiencial. Do ponto de vista prático, aponta que a aplicação deliberada de um programa voltado para a construção da cultura de inovação provoca a aprendizagem de habilidades individuais e coletivas favoráveis à inovação, além de mudanças comportamentais e organizacionais.

Design/metodologia/abordagem: Para a elaboração do relato do programa, utilizou-se observação participante, e, para a avaliação dos resultados, adotou-se uma pesquisa ex post facto baseada em entrevistas em profundidade. A análise baseou-se na semiótica fenomenológica com suporte do software Atlas. $\operatorname{Ti}^{\circledR}$ no processo de descrição, redução e interpretação, para apreender a consciência da experiência dos sujeitos.

Resultados: Os seguintes resultados foram obtidos: 1. a ocorrência de aprendizagem coletiva pela consciência da construção de soluções com base no cruzamento e na combinação de ideias de sujeitos com perspectivas e habilidades diferentes, e pela aplicação deliberada de um método e de um processo; 2 . a construção de um novo sentido coletivo para a inovação, como uma realização em constante movimento, que requer mudanças comportamentais concretas, e um novo olhar sobre a realidade. $\mathrm{O}$ estudo apontou ainda que a abordagem teórica que considera a inovação como um processo social de aprendizagem experiencial contribui para a compreensão de como se dá a construção da cultura de inovação e que esta é parte do processo de construção da inovação propriamente dita.

\section{PALAVRAS-CHAVE}

Inovação. Inovação organizacional. Cultura de inovação. Gestão da inovação. Aprendizagem organizacional.

\section{REFERENCES}

Ahmed, P. K. (1998). Culture and climate for innovation. European Journal of Innovation Management, 1(1), 30-43. doi:10.1108/14601069810199131

Brettel, M., \& Cleven, N. J. (2011). Innovation culture, collaboration with external partners and NPD performance. Creativity and Innovation Management, 20(4), 253-272. doi:10.1111/j.1467-8691.2011.00617.x 
Bruno-Faria, M. F., \& Fonseca, M. V. A. (2014a). Cultura de inovação: Conceitos e modelos teóricos. Revista de Administração Contemporânea, 4, 372-396. doi:10.1590/1982-7849rac20141025

Bruno-Faria, M. F., \& Fonseca, M. V. A. (2014b). Medidas de cultura de inovação e de cultura organizacional para análise da associação com inovação. Revista de Administração e Inovação, 11 (3), 30-55.

Bruno-Faria, M. F., \& Fonseca, M. V. A. (2015). Medida da cultura de inovação: Uma abordagem sistêmica e estratégica com foco na efetividade da inovação. Revista de Administração e Inovação, 12(3), 56-81.

Buch, A., \& Elkjær, B. (2015). Pragmatism and practice theory: Convergences or collisions. Organizational Learning, Knowledge and Capabilities Conference (OLKC), Milan, Italy.

Crossan, M., \& Apaydin, M. (2010). A multi-dimensional framework of organizational innovation: A systematic review of the literature. Journal of Management Studies, 47(6), 1154-1191. doi:10.1111/j.1467-6486.2009. 00880.x

Davies, M., \& Buisine, S. (2018) Innovation culture in organizations. In M. Chouteau, J. Forest, \& C. Nguyen. Science, technology and innovation culture (Vol. 3). Washington: Iste. doi:10.1002/9781119549666.ch6

Dewey, J. (1981). Experience and nature. In J. Dewey. The Later Works, 19251953 (Vol. 1). Illinois: Southern Illinois University Press.

Dewey, J. (1987). Art as experience. In J. Dewey. The Later Works, 1925-1953 (Vol. 10). Illinois: Southern Illinois University Press.

Dewey, J. (1998). Experience and education. West Laffayette: Kappa Delta Pi.

Dobni, C. B. (2008). Measuring innovation culture in organizations: The development of a generalized innovation culture construct using exploratory factor analysis. European Journal of Innovation Management, 11 (4), 539-559. doi:10.1108/14601060810911156

Dyer, J., Christensen, C., \& Gregersen, H. (2011). The innovator's DNA: Mastering the five skills of disruptive innovators. Brighton, MA: Harvard Business Review Press.

Elkjær, B. (2000). The continuity of action and thinking in learning: Revisiting John Dewey. Outlines. Critical Practice Studies, 2(1), 85-104.

Elkjær, B. (2004). Organizational learning: The third way. Management Learning, 35(4), 419-434. doi:10.1177/1350507604048271

Gomes, G., Machado, D., \& Alegre, J. (2015). Determinants of innovation culture: A study of textile industry in Santa Catarina. Brazilian Business Review, 12(4), 99-122. doi:10.15728/bbr.2015.12.4.5 
Harbi, S. E., Anderson, A. R., \& Amamou, M. (2014). Innovation culture in small Tunisian ICT firms. Journal of Small Business and Enterprise Development, 21 (1), 132-151. doi:10.1108/JSBED-06-2013-0086

Hill, L., Brandeau, G., Truelove, E., Lineback, K., \& Johnson, K. (2014). Collective Genius: The art and practice of leading innovation. Brighton, MA: Harvard Business Review Press.

Instituto Superior de Administração e Economia (2017). Ata de reunião do Comitê de Inovação. Curitiba: Isae.

Kaasa, A., \& Vadi, M. (2010). How does culture contribute to innovation? Evidence from European countries. Economics of Innovation and New Technology, 19(7), 583-604.

Lanigan, R. (1997). Capta versus data: Método e evidência em comunicologia. Psicologia: Reflexão e Crítica, 10(1), 17-45. doi:10.1590/S0102-79721997000 100004

Lanigan, R. (2013). Communicology and culturology: Semiotic phenomenological method in applied small group research. The Public Journal of Semiotics, 4(2), 71-103.

Martins, E. C., \& Martins, N. (2002). An organisational culture model to promote creativity and innovation. Journal of Industry Psychology, 28(4), $58-65$.

Meroni, A., \& Sangiorgi, D. (2011). Design for services. Aldershot, UK: Gower.

O'Reilly, C. A., \& Tushman, M. L. (2007). Ambidexterity as a dynamic capability: Resolving the innovator's dilemma. Boston, MA: Harvard Business School. Retrieved from http://www.hbs.edu/faculty/Publication\%20Files/07088.pdf

Osterwalder, A., \& Pigneur, Y. (2011). Business Model Generation: Inovação em modelos se negócios. Rio de Janeiro: Alta Books.

Pimentel, R. (2019) Cultura de inovação em uma escola de negócios: Um estudo inspirado pela teoria da prática. Revista Eletrônica de Ciência Administrativa, 18(4), 68-89. doi:10.21529/RECADM.2019003

Schumpeter, J. A. (1982). Teoria do desenvolvimento econômico: Uma investigação sobre lucros, capital, crédito, juro e o ciclo econômico. São Paulo: Abril Cultural.

Smith, M., Busi, M., Ball, P., \& Meer, R. V. (2008). Factors influencing an organisation's ability to manage innovation: A structured literature review and conceptual model. International Journal of Innovation Management, 12(4), 655-676. doi:10.1142/S1363919608002138 
Stickdorn, M., \& Schneider, J. (2010). This is service design thinking. Amsterdam: BIS.

Swedberg, R. (2006). Social entrepreneurship: The view of the young Schumpeter. In C. Steyaert \& D. Hjorth. Entrepreneurship as social change: A third movements in entrepreneurship book (pp. 21-34). Cheltenham: Edward Elgar.

Swedberg, R. (2009). Schumpeter's full model of entrepreneurship: Economic, non-economic and social entrepreneurship. In R. Ziegler. An introduction to social entepreneurship: Voices, preconditions, contexts (pp. 77-106). Cheltenham: Edward Elgar.

Uzkurt, C., Kumar, R., \& Ensari, N. (2013). Assessing organizational readiness for innovation: An exploratory study on organizational characteristics of innovativeness. International Journal of Innovation and Technology Management, 10(4), 1-26. doi:10.1142/S0219877013500181

Uzzi, B. (1996). The sources and consequences of embeddedness for the economic performance of organizations: The network effect. American Sociological Review, 61 (4), 674-698. doi:10.2307/2096399

Uzzi, B. (1997). Social structure and competition in interfirm networks: The paradox of embeddedness. Administrative Science Quarterly, 42(1), 35-67. doi: $10.2307 / 2393808$

Ziegler, R. (2010). Innovations in doing and being: Capability innovations at the intersection of Schumpeterian political economy and human development. Journal os Social Entrepreneurship, 1(2), 255-272. doi:10.1080/19420 676.2010 .511818

\section{AUTHOR NOTES}

Ricardo Pimentel, Ph.D. from the Master and Doctorate Program in Administration (PMDA), Positivo University (UP); Gustavo F. Loiola, Master from the Professional Master's Program in Governance and Sustainability, Higher Institute of Administration and Economics (Instituto Superior de Administração e Economia - Isae); Thiago M. Diogo, Master student of the Professional Master's Program in Governance and Sustainability, Higher Institute of Administration and Economics (Instituto Superior de Administração e Economia - Isae).

Ricardo Pimentel is now associate professor at the Professional Master's Program in Governance and Sustainability of the Higher Institute of Administration and Economics (Instituto Superior de Administração e Economia - Isae); Gustavo F. Loiola is now sustainability supervisor and coordinator of international programs of Isae Brasil Faculty of the Higher Institute of Administration and Economics (Instituto Superior de Administração e Economia -Isae); Thiago M. 
Diogo is now coordinator of the Cooperativism Innovation Program of the Higher Institute of Administration and Economics (Instituto Superior de Administração e Economia - Isae).

Correspondence concerning this article should be addressed to Ricardo Pimentel, Avenida Visconde de Guarapuava, 2943, Centro, Curitiba, Paraná, Brazil, CEP 80010-100.

\section{EDITORIAL BOARD}

Editor-in-chief

Gilberto Perez

Associated Editor

Janaina Macke

Technical Support

Vitória Batista Santos Silva

\section{EDITORIAL PRODUCTION}

Publishing Coordination Jéssica Dametta

Layout Designer
Emap

Editorial Intern

Paula Di Sessa Vavlis

Graphic Designer

Libro

Language Editor

Daniel de Almeida Leão 